\title{
DEL MUNDO MEDIEVAL AL MODERNO: CAMBIO DEVOCIONAL Y CONFLICTO SOCIAL. EL EJEMPLO VALENCIANO DE LAS COFRADÍAS DE LLÍRIA (SIGLOS XV-XVI)*
}

\author{
POR \\ JOSÉ ANTONIO LLIBRER ESCRIG² \\ Universitat de València
}

\section{RESUMEN}

Mediante el análisis del conflicto que se generó entre las cofradías de una pequeña ciudad valenciana del interior, Llíria, a mediados del siglo XVI, se explican sus características y las causas que dieron lugar a su diferente evolución posterior. Analizamos también el complejo contexto socioeconómico y religioso-cultural de transición al mundo moderno en el que se produjeron las importantes transformaciones en los aspectos espirituales y devocionales que afectaron al mundo confraternal, y que en el espacio valenciano dieron lugar a la extensión de las agrupaciones relacionadas con la Pasión y la Sangre de Cristo a lo largo de todo el siglo XVI.

PALABRAS CLAVE: Cofradías; Sangre de Cristo; cambio devocional; Reino de Valencia; Llíria; siglo XVI.

\section{FROM THE MEDIEVAL TO THE MODERN WORLD: DEVOTIONAL CHANGE AND SOCIAL CONFLICT. THE EXAMPLE OF THE VALENCIAN CONFRATERNITIES IN LLIRIA $\left(15^{\text {TH }}-16^{\text {TH }}\right.$ CENTURIES)}

\begin{abstract}
Through the conflict of the confraternities in Lliria -small city of the Ancient Kingdom of Valencia-, we analyze their characteristics, especially of the confraternitie of Christ's Blood, and analyze the causes of their different evolution throughout the $16^{\text {th }}$ century. We also explain the socioeconomic and religious context of these changes, that affected confraternities and brotherhoods intensely, and in the Ancient Kingdom of Valencia this context made the birth of a lot of fraternities of Passion and Christ's Blood possible during all the $16^{\text {th }}$ century and years later.
\end{abstract}

KEY WORDS: Confraternities; Christ's Blood; devotional change; Kingdom of Valencia; Lliria; $16^{\text {th }}$ century.

Cómo CITAR ESTE ARTículo / CITATION: Llibrer Escrig, J. A. 2019. «Del mundo medieval al moderno: cambio devocional y conflicto social. El ejemplo valenciano de las cofradías de Llíria (siglos XV-XVI)». Hispania Sacra 71, 143: 165-177. https://doi. org/10.3989/hs.2019.012

$\begin{array}{ll}\text { Recibido/Received } & 15-11-2017 \\ \text { Aceptado/Accepted } & 24-01-2018\end{array}$

\footnotetext{
El presente trabajo ha sido realizado en el marco del proyecto de investigación «Identidades urbanas Corona de Aragón-Italia: redes económicas, estructuras institucionales, funciones políticas (siglos XIV-XV)», referencia HAR2012-28861, financiado por el Ministerio de Ciencia e Innovación, y dirigido por el prof. Paulino Iradiel Murugarren, catedrático del Dept. d'Història Medieval de la Universitat de València. Y también en el proyecto «Entreprises rurales en Méditerranée occidentale, XIIle-XVle siècles (ERMO)», 2014-2017, organizado por la Casa Velázquez de Madrid y coordinado por la prof. Catherine Verna (Université Paris 8).

2 j.antonio.llibrer@uv.es / ORCID iD: https://orcid.org/0000-0002-1161-6594
} 


\section{Planteamiento}

El 14 de abril de 1574, en plena Semana Santa, a las puertas de la Casa de Jesucrist, un antiguo hospital y ahora iglesia del Bon Pastor de la villa de Llíria, población cercana a Valencia, se produjo un violento enfrentamiento entre los cofrades de la Confraria de Jesucrist i de la Verge Maria, y los de la recientemente fundada Confraria de la Preciosa Sang de Jesucrist, porque estos últimos pretendían acceder al inmueble para iniciar desde allí la procesión de disciplinantes del próximo Viernes Santo. Llegaron a las manos y se produjo un gran escándalo - vingueren a les mans ab aquells ab gran scàndol i avalot - que sólo pudo parar la llegada del Justicia local. Finalmente, los nuevos cofrades entraron a la iglesia y la ocuparon, e se apoderaren de aquella, ante la mirada de numerosos vecinos. El episodio no era aislado, sino un capítulo más del conflicto que se había generado entre las dos cofradías (la primera más antigua, fundada a finales del siglo XIV; la segunda fundada hacia 1565) precisamente por la ocupación de la Casa de Jesucrist para organizar e iniciar la procesión penitencial del Viernes Santo. Hasta tal punto el conflicto tuvo trascendencia, que llegaron a intervenir las dos administraciones de la época; en efecto, las dos cofradías acudieron a los tribunales a defender sus derechos: mientras la antigua Confraria de Jesucrist acudió a la autoridad monárquica -la Real Audiencia-, la nueva Confraria de la Sang acudió al arzobispado de Valencia, que incluso llegó a enviar a Llíria a su procurador fiscal para imponer su sentencia bajo pena de 4.000 sueldos, sin duda una pequeña fortuna de la época. ${ }^{2}$

Numerosas preguntas surgen de tan interesante conjunto de sucesos: ¿por qué el enfrentamiento entre cofradías vecinas?, ¿es la ocupación de un inmueble por unos días la causa de tal conflicto?, ¿por qué se acude a administraciones distintas, y en base a qué argumentos y derechos se accede a las denuncias? Y en el fondo, ¿qué hay detrás de tal conflicto?, ¿cómo interpretar tal conjunto de actos y toda la amplia documentación que generó?, ¿a qué nos remite este suceso desde el punto de vista de las formas de asociación, de religiosidad o de devoción?

El origen de las cofradías religiosas, su evolución, sus bases, su transformación, su cuerpo devocional, siguen siendo hoy temas y argumentos clave, y fundamentales, para intentar una explicación y una comprensión de las profundas transformaciones que la amplia crisis de los últimos siglos medievales generó en la sociedad bajomedieval, y en el tránsito que ello supuso hacia el mundo moderno. Lo que las cofradías implican en relación a su cuerpo social, a las formas de asociación y sociabilidad, a lo que suponen en el contexto urbano en relación a la emergencia de la sociedad civil, a las nuevas formas de religiosidad, a las manifestaciones de piedad y devoción, a las propuestas culturales y artísticas..., todo ello nos recuerda que su estudio continúa siendo hoy determinante para el conocimiento de estos periodos de transición donde en un amplio juego de correlaciones interestructurales se van transformando las relaciones sociales, los sistemas de representación, las formas y signos de identidad religiosa y cultural, y las propias mentalidades colectivas; aspectos que tan difíciles son de arañar

\footnotetext{
2 El proceso se encuentra en el Archivo del Reino de Valencia, en adelante ARV, Sección Reial Audiència, Procesos I, Sig. 368, año 1574.
}

al pasado, y que a través de un interesante conjunto documental conservado - y en buena parte aún inédito- de las cofradías de una ciudad cercana a Valencia, Llíria, vamos a intentar entrever.

Nuestro trabajo pretende ser, además, una aportación al estado de la cuestión sobre el porqué de la implantación devocional de las Cofradías de la Sangre de Cristo en ámbito peninsular y, en concreto, en la Corona de Aragón a lo largo del siglo XVI, frente a otras formas de asociación surgidas siglos antes, o frente a las cofradías de la Vera Cruz, que parecen imponerse en otros ámbitos en la misma cronología del Quinientos. ${ }^{3}$ Ya se ha explicado con detalle el conjunto de factores que permiten el desarrollo de este tipo de cofradías dedicadas a la Sangre de Cristo en el espacio peninsular, y en el periodo de transición del mundo medieval al moderno. ${ }^{4}$ En realidad las respuestas deben buscarse y asociarse a un contexto más amplio que implique un análisis comparado de las formas de religiosidad y sociabilidad desde el siglo XIII hasta bien entrado el siglo XVI, y con aquello que se ha dado en denominar la devotio moderna. En este extenso movimiento de piedad, apreciable en cualquier rincón del país, deben también tenerse en cuenta otros fenómenos tan relevantes como la emergencia de la sociedad civil, de los grupos populares y de sus procesos de ascenso social, tanto en ámbito urbano como en áreas rurales, y de forma complementaria, con el despertar de la conciencia del laicado y su acción en las formas de religiosidad.

En realidad, Llíria es una más de las localidades donde se fundó Cofradía de la Sangre de Cristo, en un amplio movimiento, ya estudiado, que recorrió todo el conjunto peninsular, y en especial el antiguo Reino de Valencia, iniciándose desde la propia capital y salpicando una parte importante de sus comarcas: Valencia antes de 1535, Alcoi diez años después, Cullera en 1546, Castelló en 1549, Alcalà de Xivert en 1552, Oliva en 1559, y también Xàtiva, Llíria, Manises, Pego, Ontinyent, Castalla, Xixona, Elx, Benigànim, Picanya, Nules, Vila-real, Segorbe... ${ }^{5}$ Un extraordinario movimiento fundacional que seguirá durante la centuria siguiente (Foios, Catarroja, Alzira, Algemesí, Sueca, Faura, Gilet, Xèrica, Morella, Vinaròs, Moixent, Bocairent, Enguera, Onil...) conformando un auténtico desarrollo devocional único en la Corona de Aragón durante el Antiguo Régimen. Además, no olvidemos que este movimiento se dio a la vez en diócesis distintas (de Valencia, Orihuela, Segorbe y Tortosa), lo que parece indicar que nace también desde la iniciativa de la sociedad civil, configurando un movimiento religioso muy particular y de gran dinamismo.

Otro detalle que confirma este punto hace referencia a la escasa jerarquía urbana que manifiesta. Es decir, la fundación en el siglo XVI de estas cofradías bajo la advocación de la Sangre de Cristo no sólo está presente en grandes centros urbanos (Valencia, Xàtiva, Segorbe, Alzira,

3 En el ámbito de la Corona de Aragón: Benítez Bolorinos 1998; Navarro Espinach 2005, 2006, 2014; Moros Claramunt 2016. A nivel más amplio, Sánchez Herrero 1996, 2003. Importante acopio bibliográfico en Sánchez Herrero y Ruiz Domínguez 1997; Martín-Viveros Tajuelo 2012 y también en Navarro Espinach 2014: 109-112.

4 Vid. especialmente Sánchez Herrero 1987. También Sánchez Herrero 1996 y 2003.

5 Para seguir la cronología fundacional vid. Moros Claramunt 2016: 260-277. 
Orihuela, que rondan o superan con margen el millar de fuegos en las primeras décadas del Quinientos, y que son sin duda los mayores núcleos del reino), ${ }^{6}$ también implica a localidades de tamaño medio, las quasi città de las que habla Chittolini, ${ }^{7}$ como Ontinyent, Alcoi, Elx, Llíria, Sagunt, Castelló, Onda (con demografía de entre 600 a 400 focs, y que ejercían una importante función de capitalidad comarcal, como ya se ha indicado); ${ }^{8}$ pero además se hacen presentes en pequeñas villas o comunidades con población que se situaba entre las doscientas y trescientas casas (Nules, Catarroja, Paterna, Manises, Sueca, Cullera, Pego, Castalla, Xixona); pero sobre todo, y éste es sin duda el fenómeno más interesante, estas nuevas cofradías aparecieron también en pequeñas comunidades rurales con un número de familias muy limitado (Viver, el Toro, Soneja, Gilet, Faura, Foios, Picanya, Guadassuar, Enguera...). El fenómeno es más bien horizontal hasta llegar a configurar, como decíamos, una característica definitoria de la identidad religiosocultural del país en la entrada al mundo moderno. Que la diócesis de Valencia fuera la primera a la que le fue concedida, por la Santa Sede y mediante bula de Pablo III, la celebración de la fiesta de la Sangre de Cristo, con oficio propio, el 14 de abril de $1540,{ }^{9}$ no era nada casual, y venía a manifestar de forma muy temprana el arraigo popular de esta devoción que circulaba por ciudades, villas y pueblos valencianos sin distinción.

Las causas de este interesante y casi único proceso de expansión devocional, pero también cultural, han estado ya en parte explicadas. Un amplio conjunto de causas, algunas asociadas al mismo contexto valenciano, otras en relación a fenómenos más amplios y generales, contribuyeron a esta expansión confraternal. Los trabajos de Germán Navarro y más recientemente de Baltasar Moros, permiten disponer ya de un complejo aparato conceptual sobre el proceso indicado, que me limito a resumir: ${ }^{10}$ la devoción a la humanidad de Cristo, relacionada con el dominio y la custodia de los lugares que vieron al Jesús histórico en Tierra Santa, también la influencia de la espiritualidad franciscana, que no hacen sino aumentar el interés por la pasión y muerte de Jesús, por sus sufrimientos de redención y por todos sus aspectos y símbolos relacionados; las imágenes de Cristo crucificado, el descendimiento, el Via Crucis, también los aspectos más materiales de esta pasión llegaron a suscitar el interés devoto de los creyentes, de pontífices y monarcas, pero también de gentes del pueblo, de campesinos y artesanos que participaban con profundo sentimiento de los padecimientos de Jesús en la cruz; estos elementos de fisicidad asociados a la Pasión -los fragmentos del madero de la Cruz, las espinas, la Sábana Santa, la santa Faz, etc.se convirtieron en valoradas y apreciadas reliquias; la

6 Las cifras de fuegos son las aportadas por el censo que en 1510 las Cortes valencianas encargaron para facilitar la recaudación destinada a varias campañas militares de Fernando el Católico en el norte de África. Este trabajo de cuantificación de los oficiales reales dio lugar al primer censo más o menos exhaustivo de la Edad Moderna valenciana, vid. Guinot Rodríguez 1992.

El concepto resulta altamente operativo para definir estas pequeñas ciudades o villas, Chittolini 1990.

8 Iradiel 1992b, 1999; Cruselles 2006; Mira 2005; Llibrer 2014.

9 Moros Claramunt 2016: 255.

10 Remito al lector al desarrollo explicativo más amplio de las causalidades en las obras citadas en la nota 3. llegada del Santo Cáliz a la ciudad de Valencia, en 1437 como donación de Alfonso $\mathrm{V}$, junto con otras reliquias importantes como un fragmento de la Vera Cruz, supuso un impacto determinante en toda la diócesis, hasta el punto que todavía hoy siguen siendo tesoro y emblema. Pero más allá de este fenómeno de las reliquias -no tanto taumatúrgico, como se ha dicho, sino más bien de confirmación devocional-, otras manifestaciones asociadas fueron además contribuyendo al arraigo de esta interesante identidad pasionista; la extensión de las procesiones de disciplinantes en ámbito valenciano es bien conocida, y muy relacionada a la predicación de san Vicent Ferrer; ${ }^{11}$ la predicación y el magisterio del santo dominico permitió y facilitó la circulación y el arraigo popular de esta tendencia cristocéntrica, pasionista y penitencial.

En territorio valenciano converge además como otra de las causas la importancia de distintos milagros eucarísticos, producidos en pequeñas comunidades o entornos campesinos, y con participación de gentes humildes del campo: Llutxent (1244), Alboraia (1384), Mislata (1553), ${ }^{12}$ siguen todavía presentes en la tradición religiosa y cultural de estas villas, y en aquel momento supusieron el arranque o la afirmación devocional al cuerpo y la sangre de Cristo. Devoción que también hay que poner en intensa relación a la institucionalización de la fiesta del Corpus Christi, en la segunda mitad del siglo XIII, y a lo largo del XIV en el ámbito de la Corona de Aragón. Finalmente, ya en el siglo XV y principios del XVI, y como otra de las causas que explican el amplio proceso de fundación confraternal, debemos hablar explícitamente de la devoción directa a la Sangre de Cristo: de la primera celebración de la fiesta de la Preciosa Sangre de Cristo, el 19 de junio de 1460, hasta la publicación en 1521 del conocido tratado del valenciano Andreu Martí Pineda con el elocuente título de Contemplació en Honor y Reverència de les set vegades que.l Nostre Redemptor Jesús escampà la sua Preciosíssima Sanch ab les propietats de cascuna feta, pasando por la citada bula de Pablo III en 1540, no hay sino una confirmación del progresivo asentamiento de una devoción muy concreta que marcará la identidad religiosa y cultural del pueblo valenciano en este periodo de transición.

\section{REFLEXIONES DESDE UNA VILLA VALENCIANA}

¿Qué aporta Llíria a este proceso? ¿No están ya claras y explicadas las causas y los desencadenantes de este fenómeno? ¿Qué puede aclarar un ejemplo más? ¿Qué aporta la Cofradía de la Sangre de esta pequeña ciudad? El caso de Llíria es singular, y digno de estudio, por distintas razones: la convivencia de diferentes cofradías y sus conflictos; un conjunto documental destacado; la posibilidad de acceder a sus miembros fundacionales, para conocer su perfil social y sus bases, que pueden explicar muchas cosas; su función de capitalidad en un comarca, siendo Llíria prácticamente el único enclave de población cristiana en un espacio de

11 No olvidemos que en 1394, Juan II concede licencia a los ciudadanos de Valencia para que puedan realizarse las procesiones de disciplinantes la noche del Jueves al Viernes Santo, Moros Claramunt 2016: 258.

12 Los milagros son explicados con detalle en Navarro Espinach, G. 2006: 596, y Moros Claramunt 2016: 262-263. 
comunidades islámicas, que le daban a sus manifestaciones religiosas un importante carácter identitario y de afirmación comunal. ${ }^{13}$

Desde su conquista por las tropas cristianas de Jaime I, en el año 1239 , Llíria se convierte en un punto clave para la defensa y el control del espacio interior de la ciudad de Valencia, y será durante las centurias siguientes prácticamente la única comunidad cristiana de esta amplia área interna que circunda la comarca de la capital. Dada su importancia estratégica para el mantenimiento y la defensa de las comarcas centrales del nuevo reino, los distintos monarcas siempre se reservaron su jurisdicción, convirtiéndola en una de las privilegiadas villas reales. ${ }^{14}$ Desde la llegada de los primeros cristianos, a finales de la década de 1240, la ciudad no dejó de crecer, tanto desde el punto de vista demográfico, como en su función económica y sus pautas de actividad política mediante el control de una amplia zona, la llamada Bailía de Llíria, que incluía un amplio término municipal, e incluso comunidades en la frontera turolense. Se convierte así en un "centro urbano» en el sentido que funciona como núcleo articulador de un amplio espacio agrícola, que establece además una red estable de vías y relaciones comerciales con otras ciudades, comarcas y áreas vecinas, especialmente con la ciudad de Valencia y su poderosa atracción de negocios e iniciativas. ${ }^{15}$ Estamos, en efecto, ante un proceso de desarrollo socioeconómico ligado a la aparición de su producción artesanal y de su función comercial. Y estos grupos artesanales y mercantiles cada vez irán adquiriendo mayor relevancia en la comunidad, en su oligarquía local, en sus asociaciones, en la parroquia, en sus cofradías, a lo largo de los siglos XIV y XV. La emergencia de estos nuevos grupos, de este inicial sector burgués, que se identificaba sobre todo por su pertenencia a la «comunidad», fue clave en la consolidación de ese amplio proceso devocional, dado que la pertenencia a estas asociaciones o cofradías, les facilitaba una cohesión y un corpus identitario fundamental basado en una enraizada fe común.

A mediados del siglo XVI, cuando se funda la Cofradía de la Sangre, Llíria cuenta con unos 450 fuegos, y está situada en una clara tendencia demográfica alcista (llegará a los 600 a finales de siglo) hasta situarse a la altura de las otras villas reales. ${ }^{16}$ Como se ha analizado, en este crecimiento, el papel del saldo migratorio es fundamental, a causa de la función ya indicada de Llíria como centro económico de atracción por el desarrollo de sus actividades manufactureras y mercantiles. Con todo, la villa contará en esta cronología con unos 3.000 vecinos, unas 450 o 500 familias, muchas de ellas inmigrantes, venidas de comarcas del interior, y que, como veremos, buscarán modos y espacios de integración e identificación comunitaria. Una nueva cofradía venía a ofrecer ese espacio de cohesión en una fe compartida, vivida y celebrada. Es sin duda en este contexto en el que

13 Sin duda este elemento, que poco se ha tenido en cuenta en los análisis de este fenómeno devocional a lo largo del siglo XVI, entendemos que resulta clave en algunas áreas del reino. De hecho, ninguna de las villas de la comarca, excepto Llíria, ha tenido Cofradía de la Sangre. Además, en muy pocas han aparecido, a lo largo de los siglos XVII al XX, otras cofradías de Semana Santa.

14 Llibrer 2003: 97-103.

15 Llibrer 2011.

16 López i Camps 2011. tenemos que entender la fundación de esta cofradía; y no sólo para el caso de Llíria, también para el de muchas otras villas o ciudades que pasaban por procesos similares (Onda, Sagunt, Alzira, Oliva, Ontinyent, Alcoi...). ${ }^{17}$ Esta es otra de las razones que explican porqué se fundan las nuevas cofradías de la Sangre de Cristo en muchas de estas villas cuando ya existían otras cofradías anteriores: así ocurrió, en efecto, en Xàtiva, Alzira, Onda, Vila-real o Llíria. ${ }^{18}$

En el caso que nos ocupa, debemos recordar que en esta villa del interior valenciano desde finales del siglo XIV se habían fundado al menos dos cofradías de clara función caritativa. En 1401, el infante Martín, futuro rey, y señor de la villa de Llíria, concede privilegio para la fundación de la Almoina i confraria de Nostre Senyor Jesucrist i la gloriosa Verge Maria; ${ }^{19}$ fueron dos presbíteros de origen local, que pertenecían a influyentes familias de la villa - Pere Pasqual i Julià de Sancta-, los que instaron al infante a dicha concesión, ${ }^{20}$ detalle clave para entender la vocación y el origen de esta asociación. Recordemos que la «almoina» era por definición una institución benéfica encargada de llevar a cabo acciones de asistencia social a los más pobres, generalmente mediante la limosna, el reparto de víveres, o la hospitalidad en casas de su propiedad o gestión, la llamadas "casas almoina». ${ }^{21}$ Estas asociaciones parroquiales de caridad solían financiarse mediante donaciones testamentarias o patronatos privados que en muchas ocasiones se asociaban a beneficios eclesiásticos con dotación, y lógicamente asignados a uno o más presbíteros. Así ocurrió con las dos cofradías-almoina de Llíria anteriores a la de la Sangre.

Pocos años antes de la fundación de la Almoina $i$ Confraria de Jesucrist, se había fundado en 1387 la Casa confraria de la Verge Maria, gracias a la donación privada de un vecino de Llíria, Martín Castillo, posiblemente un mercader local que en su codicilio testamentario establece la fundación de una "casa-almoina» para albergar y acoger a pobres, peregrinos y enfermos. ${ }^{22}$ Posteriormente sabemos, ya en el siglo $\mathrm{XV}$, que dos mayorales de dicha cofradía gestionaban el patronato del beneficio de San Juan Bautista y Santa Lucía, con una renta anual de 245 sueldos, fundado por el mismo Castillo para financiar dicho establecimiento.

Pero debemos ser rigurosos a la hora de valorar estas dos asociaciones, es decir, debemos analizar correctamente su origen y sobre todo su función en el ámbito local. En ambas es evidente la finalidad asistencial, y destinada a los mismos vulnerables colectivos, hasta tal punto que prácticamente nada sabemos de su actividad celebrativa o de culto público. En todo el conjunto de referencias documentales que nos han llegado de estas dos asociaciones - más de una docena- nunca se nos indica nada de su posible función celebrativa como colectivo cofrade. Sólo en un caso se nos informa de las misas que el presbítero beneficiado debe celebrar por el alma del difunto fundador, pero nada

17 Vid. bibliografía citada en nota 7.

18 En todas estas ciudades se han documentado otras cofradías, bajo otras advocaciones, fundadas en los siglos XIV y XV, Benítez Bolorinos 1998: 12-21.

19 Civera Marquino 1988.

20 Sobre la oligarquía local de la villa, y la acción comunal de sus familias, Llibrer 2004, 2007.

21 Rubio Vela 1983 y Civera Marquino 1988: 42-50. Más recientemente Llibrer Escrig 2016.

22 Civera Marquino 1988: 47-49. 
se indica de otras celebraciones, ni de su participación en procesiones parroquiales, ni en las de Semana Santa, ni tampoco se indica que participen en procesiones de disciplinantes. ${ }^{23}$ Por todo ello, más que hablar de cofradías en sentido estricto del término, deberíamos hablar, en estos dos casos, de hermandades o, por acercarnos más al término valenciano, de «almoinas». Siguiendo las aclaraciones conceptuales que explica Pérez González, una hermandad es aquella asociación de fieles a modo de cuerpo orgánico que tiene por finalidad ejercer obras de caridad o de piedad, mientras que una cofradía aporta, junto a su actividad asistencial, la función de promover y realizar el culto público, la devoción y la doctrina. ${ }^{24}$

Hablamos, por lo tanto, de asociaciones diferentes que, sin duda, así eran percibidas por los vecinos, y que llegaron a tener evolución muy distinta a lo largo del siglo XVI. El fenómeno es realmente interesante: mientras la Cofradía de la Sangre en pocos años, como veremos, ganaba cofrades y más cofrades, las otras dos asociaciones comienzan su declive hasta que, de hecho, a finales del Quinientos las dos dejan de funcionar, y en pocos años más desaparecen de la documentación prácticamente sin dejar rastro. La Cofradía de la Sangre, por el contrario, se afianza en el ámbito local y comarcal, además recibe sede propia en la Iglesia de Santa María (iglesia gótica y primera parroquia de la villa, que a mediados del siglo XVII se traslada al nuevo edificio barroco de la Asunción), va ganando también patrimonio artístico (con, al menos, cinco pasos procesionales), y hasta que en 1768 se funda la Cofradía de los Siervos de la Virgen de los Dolores -en el fondo una cofradía hermana-, será la única que organice y participe en las procesiones penitenciales de Jueves y Viernes Santo. ${ }^{25}$

23 En el largo proceso judicial que la Cofradía de la Sangre entabló con la de Jesucrist, y en la que también se cita a la de la Verge Maria, se ofrecen detalles de las procesiones de penitentes del Viernes Santa, y gracias a ello sabemos que participa la Cofradía de la Sangre pero en ningún momento se indica que lo hagan las otras dos. Entendemos que el dato es definitivo y fundamental dado que la causa principal de la denuncia es precisamente que los nuevos cofrades utilicen la sede o la casa almoina de Jesucrist para comenzar su procesión.

24 Pérez González 2016. También sobre tipologías es fundamental Arias de Saavedra y López-Guadalupe 2000. Podríamos además justificar esta diferencia en orden a otros aspectos como su origen y sus formas de financiación, aunque estos criterios parecen más difusos. Pensemos, por un lado, que las almoinas parecen surgir del interés privado e individual, y así, sus vías de financiación están generalmente en relación a las donaciones de legas testamentarias. Son así más bien "fundaciones» particulares o colectivas de donativos perpetuos para la acción caritativa. No obstante, la cofradía tiene como elemento básico de ingresos las cuotas obligatorias y establecidas de sus miembros (tanto las cuotas de entrada como las ordinarias o anuales). Con todo, no es infrecuente encontrar legados a las cofradías en testamentos, por ello las vías para financiar las actividades no siempre facilitan el establecimiento de diferencias tipológicas, ni suponen así un criterio determinante. De hecho, en ámbito valenciano, algunas cofradías administraron almoinas, y también a través de beneficios eclesiásticos. En este sentido, se establece la misma categorización o codificación que se da en otras áreas peninsulares, y podemos encontrar almoinas que no son cofradías, cofradías que contienen almoinas, y cofradías que no gestionan almoina alguna; en este sentido, y para el caso muy particular del ámbito valenciano, vid. Benítez Bolorinos 2006.

25 Alonso Tomás 1968. Sin embargo, la nueva Cofradía de la Virgen de los Dolores procesionará, y todavía lo hace hoy, el Viernes Santo por la mañana, y nunca en las procesiones vespertinas, momento exclusivo
En un intento de explicar esta divergente evolución, es momento ahora de analizar el origen, las características y la sociología de esta Cofradía de la Sangre, que además nos permitirá circular del caso particular a la explicación general, de la historia local a la aportación y al mejor conocimiento de ese fenómeno tan interesante del florecimiento de este tipo de cofradías en ámbito valenciano en los siglos XVI y XVII.

\section{ORIGEN Y SOCIOLOGÍA DE LA CofRAdíA DE LA SANGRE DE LLíRIA}

En un libro notarial de 1570, conservado en el Archivo del Colegio del Corpus Christi de Valencia, se encuentra el primer testimonio documental de la Confraria de la Preciosa Sanch de Jesucrist de la vila de Líria. ${ }^{26}$ En realidad, la cofradía se fundó años antes, en una fecha que no podemos precisar, pues en este primer documento nos aparece esta asociación con su estructura organizativa ya establecida (con prior, mayorales y un buen número de cofrades), que además dispone - según se afirma en el mismo documentode importantes ingresos, y que reclama los servicios de un notario para formalizar la autorización de ciertas acciones caritativas.

En efecto, el 12 de marzo de 1570, en plena Cuaresma, se convocó una Junta Extraordinaria de la Confraria de la Preciosa Sanch de Nostre Senyor Jesucrist, y el lugar de esta convocatoria fue, como se indica, el local de la cofradía vecina de Jesucristo - "convocats e congregats en la confraria de Jesucrist»-, donde además se nos indica que, desde su fundación, se venían reuniendo estos nuevos cofrades. ${ }^{27}$ Es decir, desde el principio, la nueva asociación ha utilizado como sede para todas sus reuniones y convocatorias un edificio ajeno, y al parecer de manera consentida. Esta primera relación entre ambas cofradías se postula interesante, y podría haber generado distinta evolución para la más antigua, tal vez mediante la integración en el grupo y las actividades de la más joven y «moderna» de la Sangre, pero, como vimos al principio, el contacto acabará en conflicto y denuncia. Al parecer la amigable relación inicial se torna incómoda en el momento que la más antigua cofradía observa pocos años después el éxito y el crecimiento de la más moderna, que ya es percibida como competidora local.

Desde el punto de vista cronológico, la aparición de esta nueva cofradía en la década de 1560, no puede desvincularse del asentamiento en Llíria de una comunidad franciscana en 1562. Este grupo de religiosos pudo promover e impulsar entre los vecinos de la villa estas nuevas prácticas de penitencia y devoción a la Pasión de Cristo, y así se ha

de la Cofradía de la Sangre hasta la actualidad, lo que nos habla de su asentamiento, su importancia y su arraigo secular en la vida local.

26 Archivo del Colegio del Corpus Christi de Valencia, en adelante, ACCV, Sección Protocolos, Sign. 20.294, notario Joan Baptista Magaluf. Debo agradecer a Joaquim López i Camps, colega investigador del Departament d'Història Moderna de la Universitat de València, la primera pista sobre tan interesante documento. Sin su información, no hubiera sido posible la localización.

27 "Tots confrares de la Confraria de la Preciosa Sanch de Jesucrist, ajustats e congregats en la confraria de Jesucrist, hon per semblants a tenir capitol per les coses concernents e tocants a dita confraria, se acostumen ajustar e congregar representants la maior e més sana part de dita confraria», Vid. la transcripción del documento en el Apéndice final. 
sugerido ya por algún autor. ${ }^{28}$ No hay duda que cofrades y franciscanos iban a compartir objetivos, praxis espiritual y actividades. Es cierto que no existe testimonio documental alguno, ni en este periodo ni en posteriores, que nos confirme la intervención franciscana en la fundación de la cofradía, pero esta interesante relación y este cruce de intereses pastorales y devocionales, no haría sino contribuir a la consolidación de la nueva hermandad y al crecimiento de su popularidad y de su seguimiento social.

El número de cofrades de la Sangre que se congregó en la Junta Extraordinaria citada fue en efecto importante: hablamos de treinta y tres cofrades, dos de ellos aparecen como mayorales, y el mismo prior, mosén Jaume Pasqual, el rector de la parroquia de Santa María (hoy conocida ya como Iglesia de la Sangre por ser su sede desde mediados del siglo XVII), que encabeza la lista de los presentes. Además, no olvidemos que uno de los elementos que hizo realmente extraordinaria esta convocatoria fue la presencia del notario Joan Baptista Magaluf, sin duda para levantar acta legal y expedir el documento correspondiente, dado que se consideraban trascendentales los acuerdos que el grupo iba a tomar durante la reunión.

Sin duda, el valor del documento es innegable, tanto por tratarse de la primera referencia a la cofradía, y en una cronología tan intensa en la que están fundándose estas primeras cofradías en el reino, como sobre todo porque nos permite conocer su vocación y su cuerpo social, el conjunto de los que serían sus fundadores, sus primeros cofrades, sus primeros miembros. Pero, ¿quiénes eran estas personas citadas? ¿Quiénes eran estos primeros mayorales y cofrades de la Sangre? ¿Qué podemos saber de todos ellos, de sus familias, de sus linajes? ¿A qué perfiles sociales responden en la comunidad de Llíria a mediados del siglo XVI? Ya podemos indicar que se trata de gentes del "común», aunque, como veremos, hay representantes de poderosas familias de la villa, de profesiones artesanales o del comercio, abundan los campesinos y labradores locales; y podemos así explicar que no se trata de una cofradía elitista de nobles o clérigos sino de un grupo de laicos o de gentes de esa emergente sociedad civil, que confirman la identidad ciudadana dominante (Vid. la lista de cofrades en la transcripción del Apéndice).

En primer lugar, debemos concretar que entre este grupo escogido de primeros cofrades encontramos familias influyentes de larga y secular presencia en la villa, y que venían formando parte de su oligarquía local desde los siglos XIV y XV: los Gerp, Jordà, Feltrer y Pasqual aparecen en los consejos municipales, y desempeñando todo tipo de cargos públicos en la administración local, también en ámbito parroquial con la fundación de capellanías, donaciones, e incluso con la construcción física de capillas familiares en el misma iglesia parroquial. ${ }^{29}$ Es especialmente interesante el caso de los Pasqual, linaje que ya hemos documentado en Llíria desde el mismo momento de la repoblación cristiana, hacia 1250; y fue una de las familias que recibió por parte del rey Jaime I, numerosas propiedades en la villa y su término. A lo largo de todo el periodo bajomedieval, se fue configurando como uno de los linajes más poderosos e influyentes tanto en el

\footnotetext{
28 Rozalén Igual 1997.

29 Llibrer 2003: 353-367.
}

ámbito civil como en el religioso; gracias a un beneficio que instituyeron a mediados del siglo XIV, construyeron su capiIla bajo la advocación de San Esteban y San Vicente Mártir, la primera de las capillas laterales de la Iglesia de Santa María, con altar y retablo propio, y que aún hoy se conserva en el edificio donde luce todavía el emblema heráldico de la familia como recuerdo secular de su activa presencia en la villa y la comunidad. ${ }^{30}$

A otras familias, como las de los Alamà, Cervera, García, Llavata, Lluesa, Martí, Martínez, Monravà, Nadal, Pérez, Ruvio (sic) o Soler, las hemos documentado en la primera mitad del siglo XV, y en buena parte de los casos nos aparecen como linajes sólidos de la villa, ya que llegaron a configurar más de diez cabezas de familia. La información que indicamos es aportada por las listas fiscales del morabatí, un impuesto que debían pagar aquellos cabezas de familia cuyo patrimonio sobrepasara el valor de 105 sueldos. Disponemos del listado de los contribuyentes del morabatí en Llíria para el año 1475, y en él encontramos a once miembros de los Alamà y los Lluesa; a diez de los Martí; nueve para los Gerp; ocho de los Cervera, seis de los Pasqual... ${ }^{31}$

Todo nos viene a indicar que los primeros mayorales y cofrades de la Sangre pertenecían a familias con arraigo en la villa, al menos de un siglo atrás, y de numerosas generaciones. En algunos casos, como hemos visto, su presencia y acción en Llíria se remonta a doscientos años más allá, y forman parte del grupo fundacional; siguiendo la denominación latina, muchos de ellos eran los «patricios», el patriciado, los «padres» de la comunidad cristiana de Llíria.

Pero con esta presencia de miembros de la oligarquía local, ¿podemos deducir que la recientemente fundada Cofradía de la Sangre de Cristo era una organización elitista y reservada sólo a familias influyentes de la comunidad? El documento citado muestra, por otra parte, individuos y familias que no pertenecían a ese grupo escogido y poderoso de vecinos con tanto arraigo en la villa, sino a gentes que residían en Llíria desde hacía muy poco tiempo; hablamos de linajes y familias llegadas recientemente, no más allá de una generación (en ocasiones incluso menos), de inmigrantes que se estaban integrando en la comunidad. Así ocurre por ejemplo con los Alfaseri (que contaban con dos cofrades, Pere y Joan), o con los Ferrandis, que están documentados únicamente desde principios del siglo XVI, desde 1510 a través del citado censo de Fernando el Católico. ${ }^{32}$

Sin embargo, y éste es un detalle muy interesante y destacable, en esa lista de principios del Quinientos todavía no aparecen las familias de algunos cofrades: ni los Bernat, ni los Fenoll, ni Herrero, ni Merino aparecen en ella. Resulta sin duda muy extraño que sólo cincuenta años antes de la fundación de la cofradía no encontremos estas familias en un censo tan completo. Dos son las razones que pueden explicar esta ausencia: por un lado, podría tratarse de familias

30 Ibídem: 182-190; Llibrer 2007: 29-32.

31 Como a finales del siglo XV, la cantidad de 105 sueldos no era muy elevada, la obligatoriedad del pago afectaría a buena parte de las familias, y la representatividad de la fuente sería por ello muy elevada. En el apéndice documental de nuestro Finestral gòtic transcribimos el listado completo, donde puede comprobarse la presencia de todos los linajes citados y su número de cabezas de familia, Llibrer 2003: 429-438.

32 La lista es publicada por López i Camps 2011: 179-186. 
de inmigrantes que no habrían llegado a la villa hasta bien entrado el siglo XVI, poco tiempo antes de la fundación; por otro lado, su ausencia podría estar en relación a sus escasos recursos, dado que, como indicábamos, al no ser considerados contribuyentes por su limitado patrimonio y posibilidades económicas, se podía prescindir de ellos en los listados fiscales. Podría ser, por tanto, que algunas de estas familias formaran parte de los grupos más humildes de la villa, hipótesis que parece altamente razonable si pensamos que en el siguiente censo fiscal conservado (de 1646), algunas de estas familias (Bernat o Fenoll) siguen sin aparecer. ${ }^{33}$ En definitiva, sea uno u otro caso, inmigración o pobreza, lo que sí resulta evidente es que esta nueva cofradía nacía con ánimo de pluralidad, de incluir a familias arraigadas e influyentes junto a otras más humildes o recién llegadas a la comunidad. La acogida de estos últimos grupos permitía precisamente a esta nueva asociación, como ahora explicaremos, llevar a cabo uno de sus objetivos básicos relacionado con la acción caritativa y solidaria.

Por lo que respecta a la actividad económica de los cofrades, las fuentes aportan poca información de oficios, lo que nos permite pensar que la mayor parte eran agricultores. Exceptuando a la familia de pelaires de los Llavata y Álvaro, ${ }^{34}$ o la de tejedores de los Sanchís, no hay más referencias a otros oficios, pero tampoco a miembros de la nobleza, de la pequeña caballería local, ni del estamento eclesiástico exceptuando el prior. Este último dato es interesante por la elevada cantidad de religiosos que residían en Llíria desde finales del siglo $\mathrm{XV},{ }^{35}$ pero que sin embargo no conformaron nunca una de las bases sociales de la nueva cofradía, que desde el principio aparece como de predominio o iniciativa seglar, de un grupo de vecinos o «ciudadanos». En efecto, el estudio sociológico de sus componentes confirma la identidad ciudadana dominante protagonizada por algunos oficios artesanales y agrícolas, de la misma forma que ocurre en la mayor parte de las nuevas cofradías de la Sangre valencianas. ${ }^{36}$

También es destacable el número de miembros treinta y tres- que aparecen como presentes en esa Junta Extraordinaria que narra el documento notarial. No podemos saber si el grupo citado conformaba el total de los cofrades, o tal vez faltaron algunos miembros, pero al menos si comparamos este número con los datos de la

33 También descartamos la posibilidad que estas familias fueran residentes en otras villas o comunidades vecinas, dado que en el documento se indica que los cofrades y sus familias, a quien puede ir destinada la acción del grupo, pertenecen a esta villa de Llíria; en efecto, se habla de "hijos de la villa [de Llíria] y cofrades».

34 Joan Álvaro, pelaire, no aparece en la lista de cofrades de 1570, pero lo documentamos como mayoral de la cofradía en el proceso judicial de 1574, donde actúa como representante de la hermandad, ARV, Reial Audiència, Procesos, I - 368 (1574, abril 14).

35 En 1494, en el momento en que se establecen Les Ordinacions de la parroquia de Santa María de Llíria, se habla ya de dieciséis presbíteros adscritos (once de ellos residen en la villa, el resto acuden a la parroquia ciertos días al año a celebrar las misas de sus beneficios o fundaciones), Llibrer 2003: 322-329; entre ellos observamos algunos linajes conocidos que décadas después estarán presentes en la nueva cofradía, como los Alamà, Feltrer, Llavata o Soler. En el censo de 1510 documentamos hasta ocho eclesiásticos (sin contar los religiosos de convento de la Trinidad), mientras que en el de 1646 la cifra asciende a dieciocho (sin contar tampoco el clero regular de los conventos franciscano y trinitario), López i Camps 2011: 179-186.

36 Navarro Espinach 2006: 606-608. población total de Llíria, podemos afirmar que casi un $10 \%$ de los cabezas de familia pertenecían ya a la recientemente fundada Cofradía de la Sangre, cifra considerable si recordamos que en la villa funcionaban desde hacía siglos otras dos asociaciones parecidas. ${ }^{37} \mathrm{El}$ interés de los vecinos por la nueva cofradía será desde el principio muy elevado. Y sin duda este éxito, este seguimiento social, será una de las causas que cuatro años después generará el conflicto entre las distintas asociaciones religiosas de la villa.

El documento notarial citado nos aporta además otros parámetros clave sobre este grupo y su asociación. Estamos, casi con toda seguridad, ante el primer documento público que generó la cofradía desde su fundación, que lógicamente tuvo que producirse años antes. Ya conocíamos el documento de la Reial Audiència en el que se narra el pleito que en 1574 mantuvo la Cofradía de la Sangre con la de Jesucristo por el uso compartido del local de esta última. ${ }^{38} \mathrm{El}$ año de este interesante documento -1574- llegó a quedar incluso en la memoria colectiva como el año de la fundación, desde que el cronista local Luis Martí lo hizo público en 1973, y así se indicaba desde la administración de la misma cofradía. ${ }^{39}$ Sin embargo, el nuevo documento notarial que hoy presentamos permite no únicamente adelantar la fundación de la institución unos diez años antes, sino que, y esto es realmente lo importante, conocer su base social, su actividad y su vocación.

¿Por qué motivo los cofrades reclamaron la presencia y los servicios del notario? ¿Con qué finalidad se convocó esta reunión extraordinaria? La causa era el debate y la posterior aprobación de una propuesta que hizo el prior, Jaume Pasqual, para que la cofradía realizara anualmente una interesante acción solidaria: se planteaba que cada año los cofrades entregaran la cantidad de 300 sueldos a alguna humilde joven hija de cofrade que lo necesitara como dote para su colocación en matrimonio. El prior explica y justifica la propuesta en base a los ingresos de la cofradía que van progresivamente en aumento, "que van día a día en aumento», como dice literalmente el prior, y así lo transcribe el notario en un magnífico estilo gramatical directo: Magnífics señors, en esta confraria per la gràcia de Nostre Senyor Déu les caritats dels confrares de aquella van de cascun dia en augment. Seria bé, señors, que puix en dita confraria ans sobra que falta, en aquell que és fer una caritat que seria una molt sancta obra e molt agradable a Nostre Señor Déu Jesucrist. ${ }^{40}$

En efecto, como en la cofradía «más sobre que falta», el ejercicio de la caridad debe marcar su acción y su vocación. En otras palabras, disponer de ingresos supone utilizarlos ya en obras de asistencia, y primero entre las familias de los mismos cofrades, después entre otros vecinos de la comunidad. Esta línea de acción solidaria será aceptada por los

37 Por otra lado, el número de treinta y tres cofrades no era casual en muchas cofradías, obedecía a la cifra simbólica de la edad de Jesús, y en ocasiones marcaba la cantidad de miembros que podía tener la hermandad, Arias de Saavedra y López Guadalupe 2000: 214-215. A mediados del siglo XVIII, sabemos que esta misma Cofradía de la Sangre de Llíria sobrepasaba ya el centenar de cofrades.

38 Fue publicado en Martí Ferrando 1974.

39 En este sentido pueden consultarse los sucesivos materiales y libros de Semana Santa que la cofradía ha ido publicando con motivo de sus celebraciones desde 1992.

40 Vid. transcripción en apéndice final. 
cofrades que incluso deciden organizarla con la complejidad que exige una donación económica: así, realizarán cada año una valoración de las posibles candidatas para elegir la más adecuada de la familia que tenga mayor necesidad, siguiendo los criterios de una conocida cofradía de la catedral de Valencia, la Confraria de la Mare de Déu de la Seu de València y Desemparats. Añaden además los cofrades un punto clave y de especial interés para la villa: si algún año no se pudiera encontrar candidata alguna para contraer matrimonio, se donarían los mismos 300 sueldos a alguna joven hija de cofrade que quisiera ingresar como beata en el monasterio de San Miguel de la misma villa - «e dita donzella volgués ésser beata de la hermita del Gloriós Arcàngel Sent Miquel»-, donde desde el siglo XIV se había establecido una comunidad de religiosas beguinas, no sometidas a la jurisdicción eclesiástica sino a la autoridad civil por su fundación y protección directamente de la corona. ${ }^{41}$ Resulta interesante que los nuevos cofrades de la Sangre decidan mantener esta peculiar comunidad de beatas que escapaban al control de la parroquia y los sacerdotes de Llíria.

Sin embargo, los cofrades parecen ser conscientes que será también difícil encontrar candidatas al eremitorio, y por ello establecen una tercera opción para poner en práctica su acción solidaria: sin jóvenes candidatas, el dinero debía destinarse a comprar toda la ropa posible que se repartiría entre los cofrades más humildes -entre los cofrades pobres, así se indica literalmente-, durante la fiesta de Todos los Santos ("e que dita roba sia repartida en confrares pobres de dita confraria en la festa de Tots Sants»). La insistencia en que estos ingresos fueran utilizados, de una u otra forma, en la ayuda a las familias cofrades más necesitadas, nos confirma, por un lado, la importancia que se daba a la caridad como objetivo y signo de identidad de la nueva cofradía, pero además nos habla de la pluralidad social en el seno de esta nueva asociación, que antes indicábamos.

Pero del documento, y de su detallada redacción, deducimos también otro aspecto importante en relación a su masa social, a su funcionamiento y gestión. No olvidemos que en la Junta Extraordinaria el prior realiza una propuesta a los cofrades para que ésta sea debatida, dialogada y aprobada con el consenso de todo el grupo. En ningún momento el presbítero muestra o realiza imposición alguna, y la misma presencia del notario confirma que la decisión es colegiada y surge de la aprobación de todo el grupo. No olvidemos que el notario se toma el esfuerzo de anotar todos y cada uno de los nombres de los cofrades presentes. Desde el principio, la cofradía nace con un interesante talante de colectividad, podríamos decir talante "cuasidemocrático», sin que nadie, ni prior ni mayorales, puedan imponer ponencia o propuesta alguna. Y hay aquí otro aspecto clave que sin duda pudo hacer atractiva y moderna esta nueva cofradía a los ojos de los vecinos y posibles cofrades. ${ }^{42}$

41 Fundado hacia 1326 por Jaime II, esta comunidad de beatas, devotes dones eremiticades, recibió numerosos privilegios reales posteriores, que la mantuvieron siempre bajo jurisdicción civil, siendo los jurados de la villa de Llíria sus administradores locales que tenían potestad de elección de la superiora y las candidatas, que debían ser "dones legítimes e honestes, fadrines o viudes», vid. AA. VV. 2006: 21-23.

42 Sobre este interesante carácter "cuasidemocrático» de las cofradías y de su relativa capacidad de autogestión, Arias de Saavedra y López Guadalupe 2000: 198-199.
El documento que analizamos concluye con la indicación del notario, por segunda vez, de que la reunión se ha celebrado en la sede de la otra asociación: «lo qual delliber fonch fet en la dita Casa de Jesucrist constituïda dins los murs de la dita vila de Llíria». Esta segunda indicación, necesaria para dar fe de lo aprobado en la Junta, no hace sino incidir en la peculiar relación que se establecía entre ambas instituciones locales, y que en un principio parecía ser pacífica. Finalmente, el notario cita a dos agricultores de la villa que estuvieron presentes como testigos de los acuerdos alcanzados: «los honrats en Jaume Sanctes e Antoni Beneyto, Ilauradors habitants de la vila de Líria». No se indica si estos dos labradores forman parte de la cofradía, o si tienen alguna relación con ésta, pero el detalle de que no sean catalogados como «vecinos» sino como «habitantes» nos lleva a pensar, como tipológicamente se establece en la documentación notarial, que se han instalado en Llíria desde hace poco tiempo, como ocurre con algunos cofrades citados anteriormente. ${ }^{43}$ De nuevo la reciente Cofradía de la Sangre parece mostrarse como elemento de integración social.

\section{CONFLICTO ENTRE COFRADÍAS}

El primer testimonio documental de esta nueva asociación nos habla del amplio seguimiento social que tuvo desde su misma fundación, de hecho, rápidamente la vemos formada por más de una treintena de miembros, con una organización ya elaborada, con unos ingresos destacables, con una interesante capacidad de integración y con la sensibilidad suficiente como para atender y cuidar a las familias más humildes de sus cofrades. La rápida fundación y organización obligó sin embargo a los de la Sangre a utilizar como sede un edificio ajeno, lo que desencadenó el citado conflicto con otra asociación vecina. Pero, insistamos en ello, no podemos hacer una lectura simplista: la ocupación o el uso de un local no fue la causa del enfrentamiento, aunque la documentación lo indique constantemente; podemos entender que el inmueble fue la excusa que aportó la parte afectada, pero, como estamos viendo, las causas refieren en buena parte a las características y la idiosincrasia de la nueva cofradía.

El análisis del proceso civil de 1574 que se conserva en la Reial Audiència nos remite siempre a los derechos de propiedad sobre la Casa de Jesucrist que gracias a privilegio real tenía la Almoina confraria de Jesucrist. En realidad, el larguísimo documento es una declaración del notario de Llíria Honorat Climent, contratado por la almoina, con el que se pretende justificar el derecho de esta última asociación a ser la única que puede y debe hacer uso del inmueble. El inicio de su exposición es un buen resumen de todos sus argumentos justificativos, y toda una declaración de intenciones: "Al effecte de verificar e provar la pacífica, quieta, antiga, titulada e immemorial possessió que aquesta part

43 La referencia al concepto "habitante» no puede ser tomada como un término aleatorio del notario, dado que en todo el resto de las páginas de su protocolo distingue con rigor a los vecinos de Llíria -la inmensa mayoría de los clientes que pasan por su mesa-, de los pocos «habitantes» de la misma villa que reclaman sus servicios, e incluso de algunos otros que son citados como "vecinos» de otras comunidades. Sobre la diferente significación de los términos, vid. Iradiel 1992b: 315-318. 
dels clavaris, majorals e confrares de la loable confraria intitulada de Jesucrist e fundada en la vila de Liria [...] tenen de la casa edificada en la dita vila de Liria, dins los murs de aquella, per a tenir los capítols e ajuts». ${ }^{44}$

Para argumentar tal propiedad, el notario remite, en primer lugar, a la fundación de aquella cofradía por parte del infante Martí, señor de la villa, a instancia de dos presbíteros vecinos; indica también que a partir de 1401 los cofrades comienzan ya a tener como sede el edificio en cuestión, un antiguo hospital convertido en ese momento en capilla. Y de todo ello queda constancia -continúa diciendo el notario-, en el libro de la cofradía, "en un libre que la dita confraria té de dits capitols y ordinacions». También se recurre al argumento consuetudinario y a testimonios de personas mayores que escucharon de sus antepasados lo que ahora se pretende explicar: "que persones antigues e de edat de la vila de Liria diran e testificaran com així sia veritat».

El siguiente argumento aportado es del todo sorprendente, y habla del elevado tono que alcanzó el conflicto confraternal: se indica con toda claridad que en la villa de Llíria no existe ni se ha fundado nunca cofradía alguna de la Sangre, y que aquellos que se denominan a sí mismos confrares de la Sanch de Jesucrist, no han tenido en la villa cofradía alguna ni tampoco ninguna sede de reunión: "consta ésser ver y se nega que en la vila de Liria hi haia confraria alguna de la Sanch de Jesucrist». La expresión inicial, "consta que es cierto» («consta ésser ver»), define la vehemencia con la que se trataba a los nuevos cofrades que ya son considerados más bien oponentes. En otras partes del documento catalogan al grupo de la Sangre como una simple "devoción» ("de la dita confraria e o devoció de la Sanch de Jesucrist; los dits pretesos confrares e o devots»), es decir, como algo que todavía está desorganizado, que no está estructurado, que no pasa de ser una simple iniciativa marginal de unos pocos. Es cierto que en este momento inicial la nueva Cofradía de la Sangre todavía no tenía aún estatutos aprobados por la autoridad eclesiástica, pero la negación de su existencia es un punto extremo que sólo se explica por la abierta rivalidad o competencia que despertaba la nueva asociación. Pero además se indica que esta "supuesta» cofradía nunca se reunió en dicha Casa de Jesucrist, ni celebró allí junta alguna, ni tampoco nunca salió en procesión de disciplinantes el Viernes Santo, ni ningún otro día, de dicha casa. De nuevo argumentos falsos (como comprobamos a través del documento notarial anterior) para facilitar su defensa, y su justificación, frente al avance y a la importancia que cada vez más adquiría la nueva cofradía entre sus vecinos.

En la argumentación que siguen proponiendo los de la antigua Almoina-cofradía de Jesucristo, se acaba minimizando la acción de los de la Sangre, indicando que aquellos que se llaman "confrares de la Sanch» son en realidad unos pocos jóvenes que han decidido, desde hace unos pocos años, disciplinarse la noche del Viernes Santo, pero sin haberse constituido cofradía con sus capítulos correspondientes: "són alguns joves e fadrins que de molts pocs anys a esta part se han volgut disciplinar en lo dia de Divendres Sant, e dient-se confrares de la Sanch de Jesucrist, no tinguen ninguna confraria ne capítols, ne algunes altres institucions

\footnotetext{
44 ARV, Reial Audiència, Procesos, I - 368 (1574, abril 14).
}

fetes sobre aquells, ne aprobades». Esgrimir el detalle de la no aprobación eclesiástica de los estatutos, cierto por otra parte, sirve como base para negar cualquier actividad de la nueva asociación.

En el siguiente justificante se habla de la tercera cofradía de la villa, la de la Gloriosa Verge Maria, para explicar que este grupo de penitentes de la Sangre solicitó años atrás a esta antigua asociación el uso de su sede -la Casa confraria de la Verge Maria - para organizar e iniciar la procesión nocturna del Viernes Santo. Pero estos tampoco accedieron nunca a la solicitud de los de la Sangre, lo que sirve ahora para hablar de una acción conjunta de las dos cofradías antiguas contra la más joven.

Parece en efecto intuirse que las dos almoinas-cofradías de Llíria ejercen una oposición común contra la más moderna de la Sangre a la que ven como amenaza compartida. Su estrategia es parecida ya que ambas se niegan a ceder sus sedes o sus casas a la nueva, a la vez que no participan de las actividades que ésta propone, como las procesiones de disciplinantes en los días clave de Semana Santa.

Finalmente, frente a la doble negativa que recibieron, los nuevos cofrades de la Sanch de Jesucrist decidieron interponer una demanda ante la autoridad eclesiástica para conseguir la cesión del local por parte de la antigua Confraria de Jesucrist. Es interesante destacar que el representante de la Sangre para llevar a cabo la denuncia ante el arzobispado no fue el prior o presbítero, ni ningún otro sacerdote de la villa, sino uno de los mayorales de ese año, Joan Álvaro, pelaire de oficio, que confirma la identidad "ciudadana» de la nueva cofradía y la importancia de su colectividad seglar.

Como ya dijimos, la autoridad eclesiástica falla a favor de los nuevos cofrades, y obliga a la cesión del local bajo pena de excomunión y 2.000 sueldos para los antiguos cofrades de Jesucristo. Ante tal fallo, estos últimos argumentan que como el edificio es de cesión real, un tribunal eclesiástico no tiene sobre él jurisdicción alguna, y deciden interponer una demanda ante los representantes de la autoridad civil. Sin embargo, antes que se produzca este proceso judicial, la autoridad de la diócesis se adelanta y obliga al cumplimiento de su citada sentencia (aumentando además la pena a 4.000 sueldos), y amenaza afirmando que enviará a Llíria a su procurador fiscal, reverent mossén Carròs, el mismo día de Viernes Santo para que se haga efectiva la cesión del local. Dos días antes, el Miércoles Santo, los cofrades de la Sangre solicitan la llave del edificio para comenzar la preparación de su procesión penitencial, y es ante la negativa a su entrega cuando el conflicto se traduce en el enfrentamiento directo narrado al principio.

Ante las amenazas y la dureza de las penas impuestas por la autoridad eclesiástica, los antiguos cofrades de Jesucristo se ven obligados a ceder las llaves y el local, pero siguen indicando que la resolución de la causa pertenece a la justicia secular, la Real Audiencia, de quien se espera sentencia, y no dudan en acusar al enviado episcopal, mosén Carrós, que finalmente acudió el Viernes Santo, de buscar y fomentar el enfrentamiento: "testificaren que lo Carròs queria fer avalot [...], e per lo terror que dit mossén Carrós les imposà, hagué en son poder les claus».

Los hechos violentos -así se describen en el proceso, «els fets violents»- son por lo tanto el resultado final de un conflicto más amplio, un conflicto que tenía que ver 
no tanto con la ocupación de un local, sino con el origen, la amplia base social, el talante, las propuestas, la nueva devoción, la capacidad de integración y otros aspectos que la nueva Cofradía de la Sangre representaba para los vecinos de Llíria. También la posibilidad de conseguir beneficios materiales, de conseguir ingresos por aumento de cofrades o donativos, podía estar detrás de estos enfrentamientos, y así se ha documentado en otros ejemplos estudiados. ${ }^{45} \mathrm{Es}$ cierto que esta causa económica por sí sola no puede explicar el conflicto citado, pero en un contexto de dificultades económicas, y asociada a otras motivaciones como el juego del prestigio social, el honor o la influencia local, nos permite entender que el motivo económico contribuía a hacer más difícil la relación confraternal en una villa con centenares de familias. El hecho mismo que la autoridad eclesiástica tomara partido a favor de la nueva cofradía, nos puede indicar que estaban en juego intereses pastorales, pero también socioeconómicos relacionados con nuevos posibles ingresos que iban a permitir una sólida acción caritativa y una mayor influencia en la villa.

Prestigio, rivalidad social, económica, devocional, simbólica, todo estaba en juego. En uno de los argumentos, ya citados, con los que la antigua Cofradía de Jesucristo pretendía defender sus derechos, se dice que los de la Sangre son un grupo de jóvenes, "jòvens e fadrins», que siguen una nueva devoción a la Sangre de Cristo ( «los pretesos confrares e o devots de la Sanch de Jesucrist»); y en estos comentarios está tal vez, subyace tal vez, una de las percepciones con que los más mayores, los de otra generación, veían a estos nuevos, que posiblemente representaban para ellos un signo de algo nuevo y diferente, un signo de la modernidad, diríamos hoy.

Y el comentario no es casual dado que, como veíamos más arriba, las dos antiguas cofradías desaparecerán en poco tiempo, en muy poco tiempo, quedando la de la Sangre como la única que representaba la adaptación a una nueva realidad religiosa, cultural y social.

\section{CONCLUSIONES DE INTENCIÓN GENERAL DESDE UNA VILLA VALENCIANA}

Devoción pasionista al Cristo sufriente que derrama su Sangre por la salvación del mundo, procesiones de disciplinantes el día de Viernes Santo, acciones de caridad hacia los más humildes, importancia del colectivo seglar, identidad ciudadana, estos son los parámetros que definen la nueva Cofradía de la Sangre de Cristo de la villa de Llíria, como son también los que definen buena parte de las decenas y decenas de cofradías que bajo la misma advocación se fueron fundando a lo largo de los siglos XVI y XVII, en ese interesante fenómeno devocional que recorrió buena parte de la península, y en especial todo el antiguo Reino de Valencia.

Y el caso de Llíria nos permite conocer cómo se iba produciendo en cada comunidad, en cada villa. La extensión de la nueva devoción pasionista a la Sangre de Cristo era tal que, en muchas localidades, grupos de fieles laicos celebraban esta festividad por iniciativa propia, e incluso realizaban sus procesiones penitenciales, sin que se hubiera fundado

\footnotetext{
45 Arias de Saavedra y López Guadalupe 2000: 219-224.
}

cofradía alguna. ${ }^{46}$ La iniciativa seglar, la emergencia de los laicos, la acción de la sociedad civil, un fenómeno sin duda más amplio, está detrás de estas nuevas propuestas y actividades.

Los dos últimos siglos medievales conforman un interesante periodo en el que se produce una transformación del cuerpo social, en buena parte como reacción a la fuerza secular de los grupos nobiliarios y aristocráticos (incluidas también las élites de los altos cargos eclesiásticos), lo que propició el progresivo desarrollo de grupos y organizaciones populares, los grupos «del común», aquello que llamamos la sociedad civil, que no es sino un amplio y heterogéneo colectivo en el que se introducían artesanos, gentes del comercio y de las finanzas, pero también agricultores y asalariados, capas populares y clases medias de enorme movilidad. ${ }^{47}$ Este activo panorama social se complicó más durante el siglo $\mathrm{XV}$, pues a causa del desarrollo económico local, esos grupos sociales urbanos (nuevos oficios artesanales y gentes del comercio, operadores mercantiles), fueron ya conscientes de su función económica, de su papel en la vida de la comunidad como generadores de empleo y de nuevas actividades, y lógicamente comenzaron a buscar vías de consolidación, de poder y de representatividad social. Pero también los campesinos medios y enriquecidos, con sus propiedades y heredades, con capacidad de gestión de sus explotaciones gracias a la amplia extensión de los sistemas de propiedad compartida enfitéutica (muy frecuentes en ámbito valenciano), formaban parte de estos nuevos grupos que buscaron su integración en la oligarquía y en los espacios de representatividad, en las nuevas instituciones y asociaciones. ${ }^{48}$ Las nuevas cofradías nacen en este fermento económico y social, en esta base popular y también de carácter ciudadano o burgués con su búsqueda de nuevas formas de acción y participación.

También por abajo, por los más humildes, y por los recién llegados, las nuevas cofradías y asociaciones posibilitaban puntos de integración y solidaridad. En efecto, una de las dinámicas básicas de estos grupos «del común» era su notable fluidez, su movilidad; así, de la misma manera que eran frecuentes los procesos y las vías de ascenso social, también lo eran los procesos de empobrecimiento y desclasamiento. Por ejemplo, la obligación de dotar y repartir el patrimonio entre los hijos e hijas, exigía a la familia campesina fragmentar parcelas y reducir el tamaño de las explotaciones; esas tierras, cada vez más pequeñas generación tras generación,

46 Según se describe en el Informe a Aranda sobre las cofradías valencianas (elaborado entre 1769 y 1772, conservado en el Archivo Histórico Nacional), en muchos pueblos, aunque no existía Cofradía de la Sangre, se celebraba especialmente la fiesta de la Preciosa Sangre de Cristo, y no por la parroquia sino por grupos de fieles que organizaban hasta la procesión respectiva; los datos los aporta Moros Claramunt 2016: 275-278. Como recuerda Vauchez, el mundo de los penitentes laicos y de las cofradías devocionales, que todavía están en buena parte por descubrir, son un ejemplo de la toma de conciencia y del rol que los laicos asumen en el seno de la iglesia, y conforman algo así como una nueva teología del laicado, Vauchez 1987: 95-96. En este sentido, es fundamental recordar los trabajos previos de Meersseman 1977; Angelozzi 1978. También del mismo Vauchez 1986. Más recientemente Gazzini 2009, sobre todo las aportaciones de M. C. Rossi, D. Zardin y F. Bianchi.

47 Para la comprensión de estos complejos procesos, resulta fundamental el extenso trabajo de Iradiel 1989.

48 Sobre este complejo proceso, en territorio valenciano: Iradiel 1988, 2003, 2007; Furió 2007; Viciano 2012. 
dificultaban la supervivencia de las nuevas familias que, además, se veían afectadas por el pago de rentas e impuestos; solicitar un crédito censal - vía muy frecuente en los siglos XIV, XV y XVI- para hacer frente a todos estos gastos, podía suponer ya el inicio del empobrecimiento: muchos campesinos se veían abocados a la venta de la poca tierra que conservaban para aligerar un endeudamiento continuado, lo que les llevaba a acercarse al grupo de jornaleros o asalariados dependientes, sin prácticamente recursos, y que en ciertas coyunturas, sólo el auxilio social y solidario de sus vecinos podía mitigar. ${ }^{49}$

Que la solidaridad de los nuevos cofrades de la sangre de Cristo fuera dirigida precisamente a dotar a una joven de familia humilde, confirma no sólo una actitud caritativa sino un contexto social muy determinado en el que nacen y se insertan estas nuevas asociaciones. Confirma también la frecuencia del ciclo de dificultades y problemas de estos grupos populares. Y era hacia los grupos más vulnerables de este "común» hacia los que dirigían su atención los de las nuevas cofradías.

La cofradía era la forma asociativa más frecuente entre colectivos ciudadanos y populares. En sus distintas caracterizaciones, religiosas y caritativas, o corporativas y gremiales, eran un magnífico reflejo de la complejidad social y económica, pero también de nuevas pautas de espiritualidad y de devoción. ${ }^{50}$ Sus elementos simbólicos, sus prácticas de fe vivida, sus manifestaciones públicas, sus acciones solidarias, todo configuraba unos valores de cohesión y pertenencia a la comunidad, pero sobre todo, parecían mostrar ya en estos ámbitos locales de raíz rural una nueva espiritualidad, una nueva forma de vivir la fe más cercana a las experiencias subjetivas e individuales, más espiritual e interiorizada y menos cúltica. Hablamos de una fe sencilla y práctica, en la que las devociones, las obras de caridad u otras prácticas religiosas fueran expresión de una reflexión y de una religiosidad interior. Es lo que se ha dado en denominar la devotio moderna. ${ }^{51}$

Frente a la mística especulativa y a la vía de la escolástica tardía, de los siglos XIII y XIV, la experiencia religiosa pasa ahora por el sentimiento, por una vía más afectiva, personal, subjetiva, cuya clave será la figura de Jesús de Nazaret. La relación con la Divinidad se manifiesta de forma distinta a la de siglos anteriores, ahora se centra en la persona de Cristo y en la dimensión humana del Cristo Jesús del Evangelio, del Jesús sufriente que desde la Cruz salva a los hombres derramando su Sangre que se extiende y vivifica a los creyentes. Así, una de las formas destacadas de la devoción popular será el interés por la Pasión de Cristo, por prácticas y obras asociadas a su sufrimiento, por nuevos grupos y cofradías que centralizaban en ella sus objetivos. La visión del Cristo sufriente, los pasos de su Pasión, su Sangre que brota de las heridas, su muerte en la Cruz, permitían tocar el interior de cada creyente, su reflexión, su dimensión personal para que posteriormente su fe se tradujera en obras exteriores, en la caridad a los más pobres, en la penitencia durante la Cuaresma, en la flagelación del propio cuerpo durante los

49 Sobre el endeudamiento campesino y la amplia extensión del crédito censal, Furió 1993, 2005; Marsilla 2002.

50 Iradiel 1992a; Benítez Bolorinos 2006: 557-563; Navarro Espinach 2014: 112-115.

51 Interesante categorización en Fernández Conde 2011: 377-416. días de Jueves y Viernes Santo. Al menos así decidieron vivir su fe un buen grupo de vecinos de Llíria, y de otras muchas villas y ciudades valencianas, que percibían la necesidad de un cambio devocional para satisfacer y expresar sus nuevas inquietudes religiosas y para establecer nuevos vínculos y procesos de cohesión social.

Es en este contexto y en este amplio conjunto de condicionantes, donde debemos comprender ese fenómeno devocional tan interesante que ocupó buena parte de la época moderna con la fundación y consolidación de decenas y decenas de nuevas cofradías penitenciales. La emergencia de la sociedad civil y los grupos populares, su diversidad y sus procesos de ascenso social y de empobrecimiento, la movilidad y el dinamismo en las áreas rurales, las nuevas formas de vida religiosa, la aparición y conciencia del laicado, la fe vivida desde nuevos parámetros, la percepción y la conciencia de una identidad religioso-cultural propia y adaptada a los nuevos tiempos, todo este conjunto de causas, o más bien de procesos, flanquearon la entrada a la época moderna en las ciudades y villas valencianas.

\section{APÉNDICE DOCUMENTAL}

1570, marzo 12. Llíria.

Junta Extraordinaria de la Cofradía de la Preciosa Sangre de Jesucristo de la villa de Llíria para la aprobación de una asignación caritativa.

ACCV, Sección Protocolos, Sign. 20.294, notario Joan Baptista Magaluf. LXXo.

Die XIIo mensis marcii, anno a Nativitate Domini $M D$

Lo reverent mossén Jaume Pasqual, prevere, prior de la Confraria de la Preciosa Sanch de Jesucrist, de la vila de Líria, Martí Martines e Pere Monravà, maiorals de dita confraria; Joan Alfaseri, menor, Thomas Cervera, Fancés Martí, Miquel Feltrer, Vicent Garcia, Martí Ferrandis, Joan Llavata, Lloís Pasqual, Francés de Lluesa, Balthasar Merino, Pere Alfaseri, Lloís Cervera, Lloís Martí, Pero Sanchís, menor, Gil Pérez, Vicent Salvador de Gerp, Miquel Jordà, menor, Pere Alamà, Nicholau Veses, Miquel Àngel Soler, Miquel Nadal, Diego Errero, Andreu Soler, Baptiste Martí, Pere Veses, menor, Andreu Fenoll, Joan Ruvio, menor, Miquel Bernat, Josep Veses e Joan Feltrer, en lloc e tots confrares de la Confraria de la Preciosa Sanch de Jesucrist, ajustats e congregats e congregats en la confraria de Jesucrist, hon per semblants a tenir capitol per les coses consernents e tocants a dita confraria, se acostumen ajustar e congregar representants la maior e més sana part de dita confraria, tots unànimes e concordes, e ningú de aquells discrepats, vista e entesa la proposició feta en lo present capítol per lo dit reverent mossén Jaume Pasqual, en dit nom, la qual proposició és la següent:

«Magnífics senyors, en esta confraria per la gràcia de Nostre Senyor Déu, les caritats dels confrares de aquella van de cascun dia en augment, seria bé, señors, que puix en dita confraria ans sobra que falta, en aquell que és fer una caritat que seria una molt sancta obra e molt agradable a Nostre Señor Déu Jesucrist que, de dites caritats, se prenguessen, col e many, quinze lliures y que elles fossen donades incontinent de alguna donzella filla de la vila y de confrare de la dita 
confraria per a que ab aquelles fos, dita donzella, col·locada e casada, puix Nostre Senyor nos augmenta les caritats de dita confraria, e axí señors vostres mercés seran instats votar e delliberar-se en dita proposició» la qual entesa tots unànimes delliberen lo que.s segueix:

Et primo, delliberen cascun any prenguen lo reverent prior que huy és e per temps serà, e maiorals axí mateix que huy són e per temps seran de dita confraria ab altres persones que aquells volran, prenguen de bens de dita confraria XV Iliures reals de València, e aquelles sien donades a una donzella filla de la vila e de confrare de dita confraria constituhida en necessitat, e fet examen de la vida, fama, onestedat e pobrea de dita donzella se e segons acostumen de fer y examinar en les confraries de la Mare de Déu de la Seu de València y Desemparats, e si no.s trobara donzella com damunt és dit per a casar, y es trobara alguna donzella, en lo modo e forma sobredit, ço és, que fos filla de la vila e de confrare de dita confraria, fet per lo semblant lo sobre dit examen, e dita donzella volgués ésser beata de la hermitta del Gloriós Arcàngel Sent Miquel, en tal cas li fossen donades les dites quinze lliures però en adjutori de dita ingressió de ser beata de dita hermitta, e si no.s troban donzella que·s pogués casar o ésser beata de Sent Miquel, en tal cas delliberen que dites XV lliures sien smercades e comprades tanto roba com se poran comprar de aquelles per los dits prior e maiorals que huy són e per temps seran de dita confraria cascun any, e que dita roba sia repartida en confrares pobres de dita confraria en la festa de Tots Sants, segons se acostuma fer en les parròchies de València, en dita festivitat de Tots Sants. Prometten servar e complir tot lo sobredit e delliberat, sots obligació dels béns de dita confraria, lo qual delliber fonch fet en la dita Casa de Jesucrist constituïda dins los murs de dita vila de Llíria dits dia, lloch mes e any.

Presents foren per testimonis a totes les dites coses, los honrats en Jaume Sanctes e Antoni Beneyto, llauradors habitants de la vila de Líria.

\section{BIBLIOGRAFÍA}

AA. VV. 2006: Sant Miquel de Llíria. Valencia: Ajuntament de LlíriaGermandat de Sant Miquel.

Alonso Tomás, M. 1968: «Fundación y centenario de la cofradía de Nuestra Señora de los Dolores», en Llibre de festes de Sant Miquel de Llíria (sin paginar).

Angelozzi, G. 1978. Le confraternite laicali: un'esperienza cristiana tra medioevo ed età moderna. Brescia: Queriniana.

Arias de Saavedra, I. y López-Guadalupe, M. 2000. «Las cofradías y su dimensión social en la España del Antiguo Régimen». Cuadernos de Historia Moderna 25: 189-232.

Benítez Bolorinos, M. 1998. Las cofradías medievales en el Reino de Valencia (1329-1458). Alicante: Publicaciones Universidad.

Benítez Bolorinos, M. 2006. "Las cofradías en el reino de Valencia. Análisis y claves interpretativas». Anuario de Estudios Medievales 36 (2): 553-581. https://doi.org/10.3989/aem.2006.v36.i2.17

Chittolini, G. 1990. «Quasi città. Borghi e terre in area lombarda nel tardo medioevo». Società e Storia 13: 3-26.

Civera Marquino, A. 1988. "Establecimientos benéficos en Llíria: pobreza, enfermedad y asistencia hospitalaria. Siglos XIV-XVII». Lauro. Quaderns d'Història i Societat 3: 39-60.

Cruselles, E. 2006. «Dinámica demográfica, red urbana e inmigración ciudadana en la Valencia bajomedieval». Saitabi 53: 35-56.

Fernández Conde, F. J. 2011. La religiosidad medieval en España. Baja Edad Media (siglos XIV-XV). Gijón: Universidad de Oviedo.
Furió, A. 1993. "Crédito y endeudamiento: el censal en la sociedad rural valenciana (siglos XIV-XV)», en E. Sarasa (coord.), Señorío y feudalismo en la península ibérica (siglos XII-XIX): 501-534. Zaragoza: Institución Fernando el Católico.

Furió, A. 2005. "Le crédit dans les registres notariaux de la région de Valence au Bas Moyen Âge», Melanges de l'Ecole Francaise de Rome 117: 407-439.

Furió, A. 2007. "Las élites rurales en la Europa medieval y moderna. Una aproximación de conjunto», en A. Rodríguez (ed.), El lugar del campesino. En torno a la obra de Reyna Pastor: 392-421. València: Universitat de València-CSIC.

Gazzini, M. (ed.) 2009. Studi confraternali: orientamenti, problemi, testimonianze. Florencia: Firenze University Press.

Guinot Rodríguez, E. 1992. "Senyoriu i reialenc al País Valencià», en Congrés Internacional Lluís de Santàngel i el seu temps: 185-202. València.

Iradiel, P. 1988. "Cristianos feudales en Valencia. Aspectos sobre la formación del territorio y de la sociedad», en España. Al-Andalus. Sefarad: síntesis y nuevas perspectivas: 49-67. Madrid: Universidad Complutense.

Iradiel, P. 1989. «Las transformaciones de la sociedad señorial, de las estructuras religiosas y de las formas de creación cultural», en P. Iradiel, S. Moreta y E. Sarasa, Historia Medieval de la España cristiana: 527-561. Madrid: Cátedra.

Iradiel, P. 1992a. «Corporaciones de oficio, acción política y sociedad civil en Valencia», en Cofradías, gremios y solidaridades en la España Medieval: 253-284.

Iradiel, P. 1992b. «L'evolució econòmica (segle XV)». De la Conquesta a la Federació Hispànica. Historia del País Valencià, vol. II: 267-324. Barcelona: Edicions 62.

Iradiel, P. 1999. "Ciudades, comercio y economía artesana», en XXV Semana de Estudios Medievales: 603-658. Pamplona.

Iradiel, P. 2003. "Metrópolis y hombres de negocios (siglos XIV y XV)», en XXIX Semana de Estudios Medievales: 277-310. Pamplona.

Iradiel, P. 2007. «El segle XV: expansió i crisi des de la perspectiva econòmica», en E. Belenguer (dir.), Història de la Corona d'Aragó, vol. I: 305-349. Barcelona: Edicions 62.

Llibrer, J. A. 2003. El finestral gòtic. L'església i el poble de Llíria als segles medievals. Valencia: Ajuntament de Llíria.

Llibrer, J. A. 2004. «De la parròquia a la confraria, de la confraria al Consell: l'elit rural baixmedieval. El cas de Llíria», en C. Santacana (coord.), Sociabilitat i ámbit local. Actes del VI Congrés Internacional d'Història Local de Catalunya: 133-145. Barcelona: I'Avenç.

Llibrer, J. A. 2007. «El retorn a les classes. L'elit rural, una mirada des de Llíria», en Mirades al Camp de Túria 3: 25-35.

Llibrer, J. A. 2011. «Diversificación económica y función mercantil: Llíria entre el mundo medieval y el moderno", en J. Hermosilla (dir.), Llíria. Historia, Geografía y Arte: 139-152. Valencia: Universitat de Valencia-Ajuntament de Llíria.

Llibrer, J. A. 2014. Industria textil y crecimiento regional: la Vall d'Albaida y el Comtat en el siglo XV. Valencia: Vicerectorat Universitat-Departament Història Medieval.

Llibrer Escrig, I. 2016. «La contabilidad para la caridad. La almoina de la catedral de Valencia, 1546». Anals de la Real Acadèmia de Cultura Valenciana 91: 9-50.

López i Camps, J. 2011. «Llíria en los siglos XVI y XVII», en J. Hermosilla (dir.), Llíria. Historia, Geografía y Arte: 155-170. Valencia: Universitat de Valencia-Ajuntament de Llíria.

Marsilla, J. V. 2002. Vivir a crédito en la Valencia medieval: de los orígenes del sistema censal al endeudamiento del municipio. Valencia: Publicacions Universitat.

Martí Ferrando, L. 1974. Crónica de la Iglesia de Santa María o de la Sangre de Liria. Valencia: Cofradía de la Sangre de Llíria.

Martín-Viveros Tajuelo, A. 2012. «Las cofradías castellanas en la Edad Media. Pasado, presente y futuro de la producción historiográfica». Espacio, Tiempo y Forma. Serie III, Historia Medieval 25: 285308. https://doi.org/10.5944/etfiii.25.2012.1687

Meersseman, G. G. 1977. Ordo fraternitatis. Confraternite e pietà dei laici nel Medioevo. Roma: Herder. 
Mira, A. J. 2005. Entre la renta y el impuesto. Fiscalidad, finanzas y crecimiento económico en las villas reales del sur valenciano (siglos XIV-XVI). Valencia: Publicacions Universitat.

Moros Claramunt, B. 2016. "Las cofradías de la Sangre en el Reino de Valencia». Cuadernos Doctorales 64: 231-291.

Navarro Espinach, G. 2005. "Las cofradías religiosas medievales en la Corona de Aragón", en Actas de las II Jornadas Nacionales de las Cofradías de la Sangre de Cristo: 25-31. Teruel.

Navarro Espinach, G. 2006. "Las Cofradías de la Vera Cruz y de la Sangre de Cristo en la Corona de Aragón (siglos XIV-XVI)». Anuario de Estudios Medievales 36 (2): 583-611. https://doi.org/10.3989/aem.2006.v36.i2.18

Navarro Espinach, G. 2014. "Las cofradías medievales en España». Historia 3964 (1): 107-133.

Pérez González, S. 2016. «Nuevas aportaciones al estudio de las cofradías y hermandades en la Castilla bajomedieval: el ejemplo de Jerez de la Frontera». Hispania Sacra 68 (138): 503-520. https:// doi.org/10.3989/hs.2016.032

Rozalén Igual, F. 1997. «Els franciscans del convent de Llíria: impulsors de la Confraria de la Sang?», en Llibre de Festes en honor de la Puríssima: 41-48. Llíria
Rubio Vela, A. 1983. Pobreza, enfermedad y asistencia hospitalaria en Ia Valencia del siglo XIV. Valencia: IVEI.

Sánchez Herrero, J. 1987. «Las cofradías de Semana Santa durante la modernidad. Siglos XV-XVIII», en I Congreso Nacional de Cofradías de Semana Santa: 27-67. Zamora.

Sánchez Herrero, J. 1996. «El origen de las cofradías de Semana Santa o de Pasión en la península ibérica». Temas medievales 6: 31-80.

Sánchez Herrero, J. 2003. «Pasión y Sangre. En torno al origen de las cofradías de Semana Santa hispana», en D. Baloup (ed.), L'enseignement religieux dans la Couronne de Castille. Incidences spirituelles et sociales (XIII'-XVe siecle): 125-142. Madrid: Casa de Velázquez.

Sánchez Herrero, J. y Ruiz Domínguez, J. A. 1997. "Las cofradías de Semana Santa. Balance de situaciones y vías de renovación», en J. Aranda Doncel (coord.), Actas del III Congreso Nacional de Cofradías de Semana Santa, vol. I: 23-64. Córdoba.

Vauchez, A. 1986. "Les confréries au Moyen Age: esquisse d'un bilan historiographique». Revue Historique 275: 467-477.

Vauchez, A. 1987. Les laïcs au Moyen Age. Practiques et experiéncies religieuses. París: Éditions du cerf.

Viciano, P. 2012. Els peus que calciguen la terra. Els Ilauradors del País Valencià a la fi de l'edat mitjana. Valencia: Publicacions Universitat. 